Research Article

\title{
Migration and Transformation of Heavy Metals in the Soil of the Water-Level Fluctuation Zone in the Three Gorges Reservoir under Simulated Nitrogen Deposition
}

\author{
Liuyi Zhang $\mathbb{D}^{1,2}$ Kun Fu, ${ }^{1}$ Fumo Yang $\mathbb{D}^{1,2,3}$ Yang Chen, ${ }^{1,2}$ Chuan Fu, ${ }^{1}$ Yimin Huang, $^{1}$ \\ Zhengjun Guo, ${ }^{1}$ and Tingzhen $\mathrm{Li}\left(\mathbb{1}^{1}\right.$ \\ ${ }^{1}$ Chongqing Key Laboratory of Water Environment Evolution and Pollution Control in Three Gorges Reservoir, \\ Chongqing Three Gorges University, Wanzhou 404000, China \\ ${ }^{2}$ CAS Key Laboratory of Reservoir Environment, Chongqing Institute of Green and Intelligent Technology, \\ Chinese Academy of Sciences, Chongqing 400714, China \\ ${ }^{3}$ National Engineering Research Center for Flue Gas Desulfurization, Department of Environmental Science and Engineering, \\ Sichuan University, Chengdu 610065, China
}

Correspondence should be addressed to Fumo Yang; fmyang@scu.edu.cn and Tingzhen Li; litingzhen@163.com

Received 9 November 2020; Revised 18 January 2021; Accepted 31 January 2021; Published 19 February 2021

Academic Editor: Stanislav Frančišković-Bilinski

Copyright (c) 2021 Liuyi Zhang et al. This is an open access article distributed under the Creative Commons Attribution License, which permits unrestricted use, distribution, and reproduction in any medium, provided the original work is properly cited.

\begin{abstract}
The accumulation of heavy metals (HMs) in the water-level fluctuation zone (WLFZ) of the Three Gorges Reservoir (TGR) area is potentially harmful to the water environment. In order to reveal whether nitrogen $(\mathrm{N})$ deposition is a potential driving factor for the migration and transformation of $\mathrm{HMs}(\mathrm{Cd}, \mathrm{Cr}, \mathrm{Cu}, \mathrm{Ni}$, and $\mathrm{Pb})$, a simulated $\mathrm{N}$ deposition experiment was performed on the soil in the WFLZ of the TGR. The results showed that the accumulative release amounts of HMs increased with the increase of $\mathrm{N}$ deposition. It was found that the Elovich equation, double-constant equation, and parabolic diffusion equation could well describe the release process of $\mathrm{Cu}, \mathrm{Cd}, \mathrm{Cr}$, and $\mathrm{Ni}$, while the double-constant equation, parabolic diffusion equation, and first-order equation could be applicable for $\mathrm{Pb}$. The exchangeable fractions of HMs increased to varying degrees after the $\mathrm{N}$ deposition treatment, wherein $\mathrm{Ni}$ was most significant, indicating that $\mathrm{N}$ deposition could increase the ecological risk of HM pollution in the TGR area. The results provide insight into the major factors affecting the release of different HMs under $\mathrm{N}$ deposition in this vulnerable region ecologically.
\end{abstract}

\section{Introduction}

The Three Gorges Reservoir (TGR) area is located in the middle and upper reaches of the Yangtze River, southwestern China. The TGR stores water from October to April and discharges water from May to September, resulting in the water-level fluctuation between $135 \mathrm{~m}$ and $145 \mathrm{~m}$, and the formation of a water-level fluctuation zone (WLFZ) with an area of $348.9 \mathrm{~km}^{2}$. Affected by the periodic flooding, the ecological environment of the WLFZ is fragile, and the related environmental problems, e.g., accumulation of heavy metals (HMs), have raised the attention $[1,2]$. Since the initial impoundment of the TGR, HMs in the WFLZ soil have shown an upward trend because of the external inputs from agricultural activities and domestic wastes [3]. Of note is that the cumulative HMs, in turn, can become the potential source of pollution and threaten the safety of the water environment.

Factors affecting the activity and mobility of HMs in the soil of WFLZ in the TGR are implicated in two aspects. Firstly, the local agricultural activities, such as plowing and fertilization in WFLZ during the period of exposure, can accelerate the migration of HMs from WFLZ to the water body of the TGR $[4,5]$. However, with the government's prohibition of agricultural activities on WFLZ, this impact has been minimal. Secondly, the changes of physical, 
chemical, and biological properties of soil under periodic recession (oxidation) and inundation (reduction) can cause the transformation and migration of HMs. Related research studies have made great progress [6].

Agricultural activities and periodic fading and flooding conditions are currently the two most concentrated researches on the migration and transformation of HMs in the WLFZ of the TGR area. To the best of our knowledge, however, the impact of precipitation on migration and transformation is rarely reported. Atmospheric precipitation, another important factor affecting the environmental behaviors of HMs in soil, involves not only physical migration but also involves chemical transformation depending on the chemical compositions of precipitation. Nitrogen $(\mathrm{N})$ is the main chemical component in precipitation, mainly in the inorganic form $\left(\mathrm{NO}_{3}{ }^{-}-\mathrm{N}\right.$ and $\left.\mathrm{NH}_{4}{ }^{+}-\mathrm{N}\right)$ and also includes a small amount of organic $\mathrm{N}$. In recent years, not only the $\mathrm{N}$ flux of wet deposition has a great increase, but the $\mathrm{N}$ forms in a wet deposition have also been changed [7]. In this case, the response of the ecological environment to $\mathrm{N}$ deposition is particularly worthy of attention.

In the TGR area, a relatively higher level of $\mathrm{N}$ flux deposition $\left(26.81 \pm 13.83 \mathrm{~kg} \mathrm{~N} \mathrm{ha}^{-1} \mathrm{yr}^{-1}\right)$ is threatening the aquatic and forest ecosystems, even some farmland ecosystems [8, 9]. Excessive $\mathrm{N}$ deposition can cause soil acidification and further increase the solubility of potentially toxic metals in soil [10]. The exposure period of the WFLZ soil coincides with the rainy season (May to September), in which wet deposition $\mathrm{N}$ accounts for about $70 \%[9,11]$. Therefore, we collected undisturbed WFLZ soil columns and performed a simulated $\mathrm{N}$ deposition experiment to study the mobility characteristics of typical HMs, aiming to explore the relationship between $\mathrm{N}$ deposition and the migration and transformation of HMs in the WFLZ soil. This information has implications for better understanding the migration and transformation of HMs in the TGR area.

\section{Materials and Methods}

2.1. Sample Collection. A gentle WLFZ was selected at $154 \mathrm{~m}$ of water-level elevation in the Tanshao village, Wanzhou District (Figure 1); 12 undisturbed soil samples were collected with clean PVC pipes $(15 \mathrm{~cm}$ in diameter and $20 \mathrm{~cm}$ in height). After collection, we covered both ends of the soil pillar samples with plastic wrap and brought them back to the laboratory for subsequent $\mathrm{N}$ addition experiment. The physicochemical properties of soil in WFLZ and concentrations of HMs are shown in Table 1. The single factor index method was applied to assess the pollution degree of HMs. The pollution index $\left(P_{i}\right)$ for each HM was expressed by the ratio of the measured concentration $\left(C_{i}, \mathrm{mg} / \mathrm{kg}\right)$ to the standard concentration $\left(C_{i}, \mathrm{mg} / \mathrm{kg}\right)$ [12]. In this study, the background value of HMs in the WFLZ was used as the standard value [13]. Based on the results of single factor index method [12], Cd belonged to a high pollution degree $\left(P_{i}>3\right)$, while $\mathrm{Cr}, \mathrm{Cu}, \mathrm{Ni}, \mathrm{Pb}$, and $\mathrm{Zn}$ belonged to clean level $\left(P_{i}<1\right)$ in the original WFLZ soil in this study (Table 1$)$.
2.2. Simulation of $N$ Deposition. According to the $\mathrm{N}$ deposition flux (20.69 $\mathrm{kgN} /(\mathrm{ha} \cdot \mathrm{yr})$ ) and the average annual rainfall $(\sim 1200 \mathrm{~mm})$ in the TGR area [8], four $\mathrm{N}$ flux groups, including $\mathrm{N}$-free group $\left(\mathrm{N}_{0}, 0 \mathrm{kgN} /(\right.$ ha $\left.\cdot \mathrm{yr})\right)$, low $\mathrm{N}$ group $\left(\mathrm{N}_{20}, 20 \mathrm{kgN} /(\right.$ ha $\left.\cdot \mathrm{yr})\right)$, middle $\mathrm{N}$ group $\left(\mathrm{N}_{40}, 40 \mathrm{kgN} /(\right.$ ha $\cdot \mathrm{yr})$ ), and high $\mathrm{N}$ group $\left(\mathrm{N}_{60}, 60 \mathrm{kgN} /(\right.$ ha $\left.\cdot \mathrm{yr})\right)$, were set, and each group was performed in triplicate. $\mathrm{N}_{0}, \mathrm{~N}_{20}, \mathrm{~N}_{40}$, and $\mathrm{N}_{60}$ were about $0,1,2$, and 3 times, respectively, of the actual $\mathrm{N}$ deposition fluxes in the TGR area. $\mathrm{NH}_{4} \mathrm{NO}_{3}$ was the only $\mathrm{N}$ source in this research, and the $\mathrm{pH}$ of each leaching solution was adjusted to 5.5, which was consistent with the local rainwater [11].

Siphon drip irrigation bags with adjustable flow rates were used to hold the leaching solution, and the flow rate was set to $0.8 \mathrm{~mL} / \mathrm{min}$ to prevent water from accumulating in the soil column. Before leaching, two $0.45 \mu \mathrm{m}$ microporous membranes at both ends of the soil column were fixed. The leaching volume was $0.5 \mathrm{~L}$ each day, and this process of leaching was continued for 40 days. $20 \mathrm{~L}$ of the total leaching volume (about $1162.6 \mathrm{~mm}$ rainfall amount) was consistent with the local multiyear average rainfall amount (about $1150 \mathrm{~mm}$ ). The schematic diagram of the simulated $\mathrm{N}$ addition device was shown in Figure 2. After finishing the daily leaching, the volume of each leachate was recorded firstly and then filtered through $0.45 \mu \mathrm{m}$ filter membrane and stored at $4^{\circ} \mathrm{C}$ for testing. Soil samples before and after eluviation were air-dried at room temperature, and then the plant roots and residues were removed. Hereafter, the soil samples were homogenized and grounded to pass through a 2-mesh sieve for determining the physicochemical properties and the metal fractions.

2.3. Sample Analysis. Soil $\mathrm{pH}\left(\mathrm{H}_{2} \mathrm{O}\right)$ was determined in 1 : $2.5(\mathrm{w} / \mathrm{v})$ soil water suspension using $\mathrm{PHS}-3 \mathrm{C} \mathrm{pH}$-meter (Shanghai Leici Instrument Co., Ltd, China). Organic matter was determined by a modified Walkley-Black method, and the detailed processes have been described elsewhere [14]. $\mathrm{NH}_{4}{ }^{+}$and $\mathrm{NO}_{3}{ }^{-}$in the samples were analyzed by an ion chromatograph (Dionex-900, Diane, USA) with detection limits of $0.005 \mathrm{mg} / \mathrm{L}$ and $0.031 \mathrm{mg} / \mathrm{L}$, respectively.

In order to determine the mobility and activity of HMs, the exchangeable fraction of typical $\mathrm{HMs}(\mathrm{Cd}, \mathrm{Cr}, \mathrm{Cu}, \mathrm{Ni}$, and $\mathrm{Pb}$ ) was extracted by the classical method [15]. In brief, $1 \mathrm{~g}$ of dried sample was extracted with $8 \mathrm{ml} \mathrm{MgCl}_{2}(\mathrm{pH}=7.0)$ and continually shaken for 1 hour at $25^{\circ} \mathrm{C}$, the extract was centrifuged at $4000 \mathrm{rpm}$, and the supernatant was made to volume in $25 \mathrm{~mL}$ volumetric flask. The residual soil was digested with a mixed acid $\left(6 \mathrm{ml}\right.$ of $\mathrm{HNO}_{3}, 2 \mathrm{ml}$ of $\mathrm{HCl}$, and $2 \mathrm{ml}$ of $\mathrm{HF}$ ) by microwave digestion instrument (Mars5, CEM, USA). HMs were determined by inductively coupled plasma optical emission spectrometry (Optima 7000, PerkinElmer, USA). The detection limits were 0.006, 0.03, 0.008, 0.33 , and $0.035 \mathrm{~g} / \mathrm{L}$, respectively. The recovery rates of samples were between $95 \%$ and $120 \%$.

2.4. Statistical Processing of Data. In this study, the doubleconstant equation (1), Elovich equation (2), first-order equation (3), and parabolic diffusion equation (4) were used 


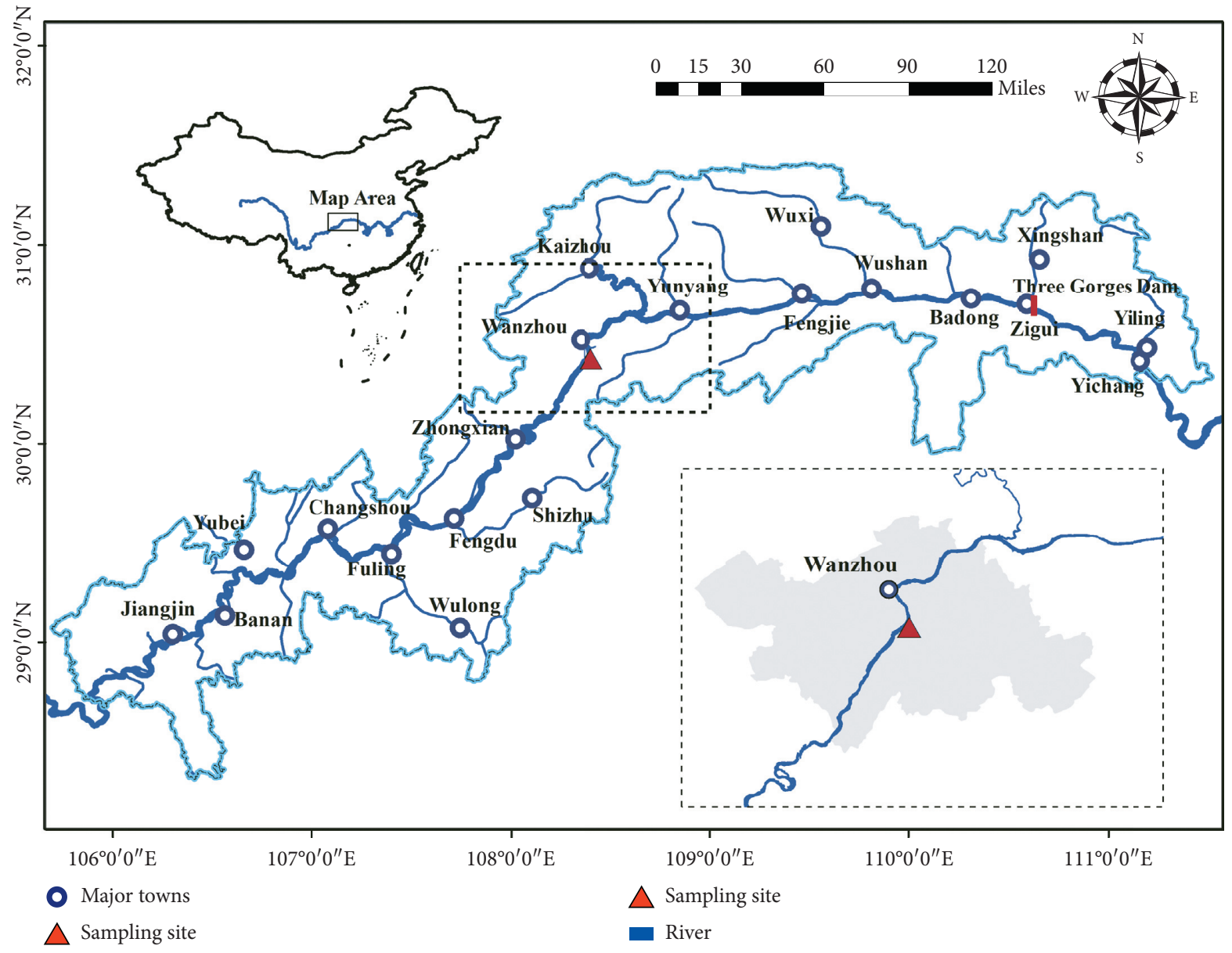

FIgURE 1: Location of the sampling site.

TABLE 1: Physicochemical properties of the original WFLZ soil in the TGR area.

\begin{tabular}{lccc}
\hline Soil indexes & Content & Background values of WFLZ in the TGR $^{\mathrm{a}}$ & Pollution degree $^{\mathrm{b}}$ \\
\hline $\mathrm{pH}$ & $8.16 \pm 0.13$ & 7.84 & n.d \\
$\mathrm{OM}(\mathrm{g} / \mathrm{kg})$ & $13.92 \pm 0.47$ & n.d & n.d \\
$\mathrm{Bulk} \mathrm{density}\left(\mathrm{g} / \mathrm{cm}^{3}\right)$ & $1.4 \pm 0.14$ & n.d & n.d \\
$\mathrm{NO}_{3}^{-}-\mathrm{N}(\mathrm{mg} / \mathrm{kg})$ & $2.13 \pm 0.007$ & n.d & n.d \\
$\mathrm{NH}_{4}^{+}-\mathrm{N}(\mathrm{mg} / \mathrm{kg})$ & $179.49 \pm 6.47$ & n.d & n.d \\
$\mathrm{Al}(\%)$ & $3.98 \pm 0.38$ & n.d & n.d \\
$\mathrm{Fe}(\%)$ & $4.88 \pm 0.49$ & n.d & n.d \\
$\mathrm{Mn}(\mathrm{mg} / \mathrm{kg})$ & $1018.66 \pm 149.05$ & n.d & n.d \\
$\mathrm{Cd}(\mathrm{mg} / \mathrm{kg})$ & $2.63 \pm 0.67$ & 0.321 & High \\
$\mathrm{Cr}(\mathrm{mg} / \mathrm{kg})$ & $76.82 \pm 5.89$ & 55.5 & Clean \\
$\mathrm{Cu}(\mathrm{mg} / \mathrm{kg})$ & $37.17 \pm 5.13$ & 37 & $\mathrm{Clean}$ \\
$\mathrm{Ni}(\mathrm{mg} / \mathrm{kg})$ & $48.46 \pm 0.95$ & 29.5 & Clean \\
$\mathrm{Pb}(\mathrm{mg} / \mathrm{kg})$ & $65.80 \pm 7.64$ & 29.3 & $\mathrm{Clean}$ \\
$\mathrm{Zn}(\mathrm{mg} / \mathrm{kg})$ & $166.82 \pm 21.89$ & 72.7 & Clean \\
\hline
\end{tabular}

${ }^{a}$ Background values of WFLZ in the TGR [13]. ${ }^{b}$ Evaluation by single factor index method [12]. n.d. means no data.

to describe the release kinetics of HMs under $\mathrm{N}$ deposition [16].

$$
\begin{aligned}
\ln S & =a \ln t+b, \\
S & =a \ln t+b,
\end{aligned}
$$

$$
\operatorname{Ln}\left(\frac{S}{S_{m}}\right)=a t+b,
$$

$$
\frac{S}{S_{m}}=a t^{1 / 2}+b
$$




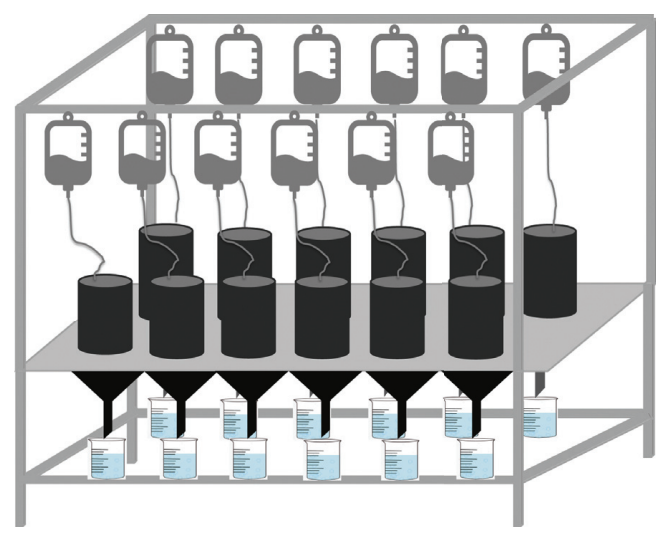

Figure 2: Leaching device of simulating $\mathrm{N}$ deposition.

where $S(\mu \mathrm{g} / \mathrm{kg})$ is the release amount of metals at a certain time, $S_{m}(\mu \mathrm{g} / \mathrm{kg})$ is the maximum release amount, $t(d)$ is the leaching time, $a$ and $b$ are the constants with different meanings for each model.

One-way analysis of variance (ANOVA) was used to test for differences between groups of $\mathrm{N}$ deposition if the data conform to the normal distribution. Otherwise, Kruskal-Wallis rank sum test was applied to test the differences. In addition, Person's correlation coefficient was used to describe the relationships between variables. These analyses were performed using IMB SPSS version 22.0 statistical software.

\section{Results and Discussion}

3.1. Cumulative Release Amount. The cumulative release amounts of HMs were different under various treatments of $\mathrm{N}$ deposition (Table 2). Both $\mathrm{Cr}$ and $\mathrm{Cu}$ were leached out more than $30 \mu \mathrm{g}$, and the amounts under $\mathrm{N}_{60}$ treatment were significantly higher $(p<0.05)$ than those under $\mathrm{N}_{0}, \mathrm{~N}_{20}$, and $\mathrm{N}_{40}$ treatments. In contrast, the release amounts of $\mathrm{Ni}$ and $\mathrm{Cd}$ were lower than $10 \mu \mathrm{g}$, and there were no significant differences $(p>0.05)$ between each $\mathrm{N}$ deposition treatment. In addition, the amount of leached-out $\mathrm{Pb}$ showed a significant difference between each $\mathrm{N}$ treatment. The results indicated that $\mathrm{Pb}$ was the most sensitive to the $\mathrm{N}$ deposition, and even a low $\mathrm{N}$ deposition load $(20 \mathrm{kgN} /($ ha yr) $)$ could stimulate the release of $\mathrm{Pb}$ from WFLZ soil. This could be ascribed to the relatively lower binding energy of $\mathrm{Pb}$ with $\mathrm{Fe} /$ Al hydro(oxide) in the WFLZ soil, which was more susceptible to the destruction of $\mathrm{N}$ deposition $[17,18]$. However, a high $\mathrm{N}$ deposition load $(60 \mathrm{kgN} /$ (ha yr)) was required to promote the release of $\mathrm{Cr}$ and $\mathrm{Cu}$ significantly. Besides, there was no significant influence on the release of $\mathrm{Cd}$ and $\mathrm{Ni}$ under the treatments of $\mathrm{N}$ deposition in this study.

3.2. Release Rate. Under the simulated precipitation leaching, HMs presented three different release stages except that $\mathrm{Cr}$ showed two stages (Figure 3). Every release stage of HMs showed a good linear relationship $\left(r^{2}>0.85\right)$, and the slopes of the linear equations can be used to represent the release rate of HMs at each stage. The linear equations
TABLE 2: Cumulative release amounts of HMs in the soil of WFLZ in the TGR area (unit: $\mu \mathrm{g}$ ).

\begin{tabular}{lccccc}
\hline Treatment & $\mathrm{Cr}$ & $\mathrm{Cu}$ & $\mathrm{Cd}$ & $\mathrm{Ni}$ & $\mathrm{Pb}$ \\
\hline $\mathrm{N}_{0}$ & $32.44 \mathrm{a}$ & $30.45 \mathrm{a}$ & $1.61 \mathrm{a}$ & $7.29 \mathrm{a}$ & $6.76 \mathrm{a}$ \\
$\mathrm{N}_{20}$ & $34.21 \mathrm{a}$ & $30.83 \mathrm{a}$ & $1.69 \mathrm{a}$ & $7.98 \mathrm{a}$ & $14.27 \mathrm{~b}$ \\
$\mathrm{~N}_{40}$ & $35.08 \mathrm{a}$ & $32.18 \mathrm{a}$ & $1.67 \mathrm{a}$ & $8.52 \mathrm{a}$ & $22.74 \mathrm{c}$ \\
$\mathrm{N}_{60}$ & $38.82 \mathrm{~b}$ & $36.08 \mathrm{~b}$ & $1.87 \mathrm{a}$ & $7.90 \mathrm{a}$ & $31.15 \mathrm{~d}$ \\
\hline
\end{tabular}

Note. The same letters mean no significant difference $(p>0.05)$ and different letters mean significant difference $(p<0.05)$ tested by one-way ANOVA.

and coefficients $\left(r^{2}\right)$ were shown in Table 3. The release rates of $\mathrm{Cr}, \mathrm{Cu}$ and $\mathrm{Cd}$ exhibited a similar variation trend, showing the fastest release rate in the first stage, and gradually decreasing in the following stages. This may be related to the contents of water-soluble ions in the soil. In the beginning stage, the metal ions in the soil water were quickly released with the wet deposition. As the leaching continued in the second stage, the adsorbed HMs were gradually leached out. In the third stage, the release rate became slower as the active ions of HMs decreased, and this stage may involve chemical transformation and desorption. Since $\mathrm{Cr}$ usually presents in the soil in the form of negative valent acid radical $\left(\mathrm{Cr}_{2} \mathrm{O}_{7}{ }^{2-}\right.$ and $\left.\mathrm{CrO}_{4}{ }^{2-}\right)$, which were hardly adsorbed by soil colloid and easily mobilized in soil [19], only a two-stage leaching process was exhibited. The cumulative release rate of $\mathrm{Ni}$ increased instead after 32 days (the third stage), probably caused by some chemically bound forms leaching out. For $\mathrm{Pb}$, the cumulative release curve fluctuated greatly, and there existed large differences in its release amount with different $\mathrm{N}$ deposition levels, pointing to more intricate physicochemical processes of soil $\mathrm{Pb}$ due to $\mathrm{N}$ deposition.

3.3. Kinetics of Cumulative Release. The first-order kinetic equation, double-constant rate equation, parabolic equation, and modified Elovich equation are the common mathematical models to describe the characteristics of dynamics of soil HMs [20, 21]. The first-order kinetic equation is good at describing the simpler surface process of the diffusion mechanism [22]. The double-constant rate equation (also known as Freundlich's correction) is an empirical formula, which is suitable for more complex kinetic reaction processes and can better describe the uneven energy distribution process and the different affinity of adsorption sites to HMs on the surface of soil particles [16]. The parabolic equation is suitable to describe the process controlled by multiple diffusers [23]. The Elovich equation is also an empirical formula, which describes a process that includes a series of reaction mechanisms, such as the diffusion of solutes at the solution phase or interface, surface activation, and deactivation [24]. The equation is suitable for the reactions with large changes in activation energy processes (such as those on sediments and soils), which are less suitable for processes with a single surface diffusion mechanism [25]. The above four equations were used to fit the leaching data obtained in this research. The fitting results are shown in Table 3. 

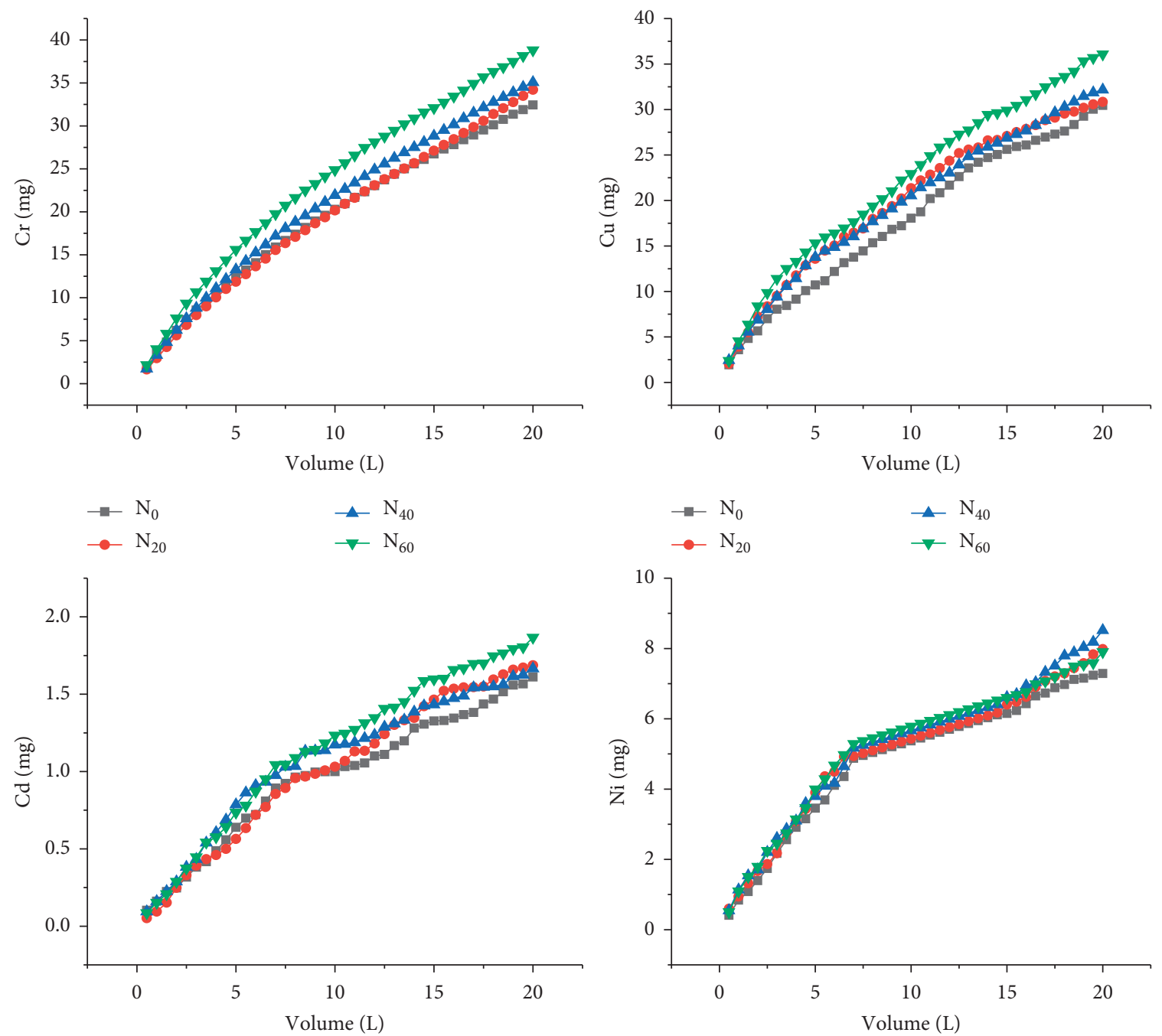

$-\mathrm{N}_{0}$
$-\mathrm{N}_{20}$
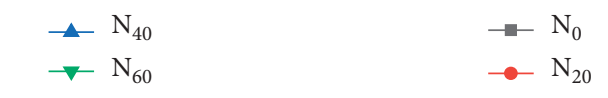

$\longrightarrow \mathrm{N}_{40}$
$\rightarrow-\mathrm{N}_{60}$

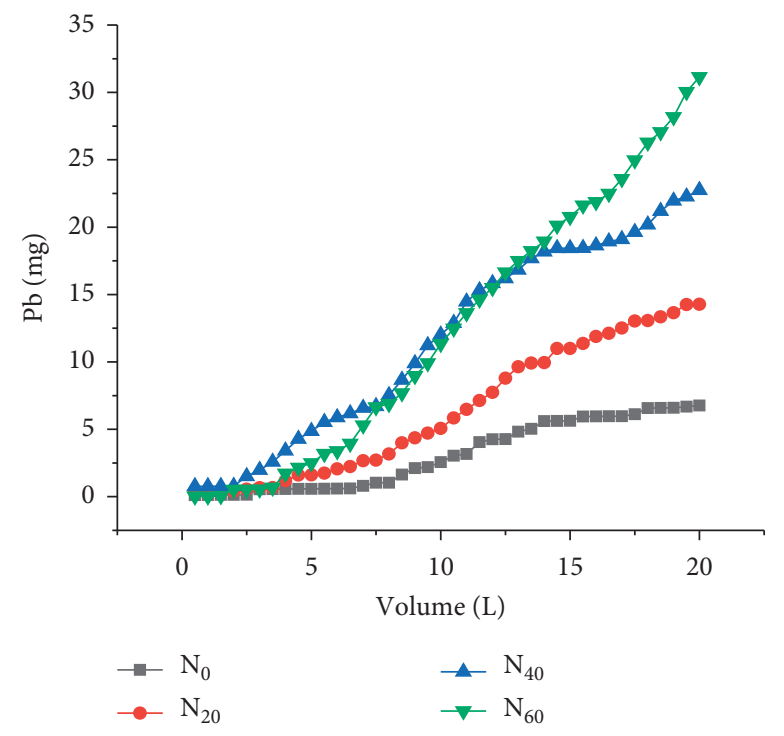

FIGURE 3: Cumulative release amounts of HMs in the soil of the WFLZ in the TGR area. 
TABLE 3: Fitting functions of cumulative release amounts and the release rates of HMs.

\begin{tabular}{|c|c|c|c|c|}
\hline $\mathrm{N}$ deposition & Release process & Fitting equation & Correlation coefficient $\left(r^{2}\right)$ & Release rate $(\mu \mathrm{g} / \mathrm{d})$ \\
\hline \multicolumn{5}{|l|}{$\mathrm{Cr}$} \\
\hline \multirow{2}{*}{$\mathrm{N}_{0}$} & First stage & $y=1.14 x+1.38$ & 0.992 & 1.14 \\
\hline & Second stage & $y=0.65 x+7.03$ & 0.996 & 0.65 \\
\hline \multirow{2}{*}{$\mathrm{N}_{20}$} & First stage & $y=1.14 x+0.84$ & 0.995 & 1.14 \\
\hline & Second stage & $y=0.72 x+5.49$ & 0.999 & 0.72 \\
\hline \multirow{2}{*}{$\mathrm{N}_{40}$} & First stage & $y=1.27 x+0.92$ & 0.995 & 1.27 \\
\hline & Second stage & $y=0.71 x+7.50$ & 0.996 & 0.71 \\
\hline \multirow{2}{*}{$\mathrm{N}_{60}$} & First stage & $y=1.48 x+1.34$ & 0.991 & 1.48 \\
\hline & Second stage & $y=0.76 x+9.63$ & 0.995 & 0.76 \\
\hline \multicolumn{5}{|l|}{$\mathrm{Cu}$} \\
\hline \multirow{4}{*}{$\mathrm{N}_{0}$} & First stage & $y=1.09 x+1.28$ & 0.982 & 1.09 \\
\hline & Second stage & $y=0.78 x+2.86$ & 0.997 & 0.78 \\
\hline & Third stage & $y=0.46 x+11.63$ & 0.989 & 0.46 \\
\hline & First stage & $y=1.43 x+1.04$ & 0.989 & 1.43 \\
\hline \multirow{3}{*}{$\mathrm{N}_{20}$} & Second stage & $y=0.78 x+5.70$ & 0.998 & 0.78 \\
\hline & Third stage & $y=0.38 x+15.66$ & 0.998 & 0.38 \\
\hline & First stage & $y=1.34 x+1.33$ & 0.997 & 1.34 \\
\hline \multirow[t]{3}{*}{$\mathrm{N}_{40}$} & Second stage & $y=0.70 x+6.39$ & 0.997 & 0.70 \\
\hline & Third stage & $y=0.54 x+10.62$ & 0.997 & 0.54 \\
\hline & First stage & $y=1.70 x+1.13$ & 0.991 & 1.70 \\
\hline \multirow{2}{*}{$\mathrm{N}_{60}$} & Second stage & $y=0.82 x+6.57$ & 0.995 & 0.82 \\
\hline & Third stage & $y=0.60 x+12.23$ & 0.996 & 0.60 \\
\hline \multicolumn{5}{|l|}{$C d$} \\
\hline \multirow{4}{*}{$\mathrm{N}_{0}$} & First stage & $y=0.06 x+0.03$ & 0.995 & 0.06 \\
\hline & Second stage & $y=0.03 x+0.51$ & 0.927 & 0.03 \\
\hline & Third stage & $y=0.03 x+0.28$ & 0.982 & 0.03 \\
\hline & First stage & $y=0.06 x-0.005$ & 0.991 & 0.06 \\
\hline \multirow[t]{3}{*}{$\mathrm{N}_{20}$} & Second stage & $y=0.04 x+0.31$ & 0.980 & 0.04 \\
\hline & Third stage & $y=0.02 x+0.88$ & 0.933 & 0.02 \\
\hline & First stage & $y=0.07 x+0.02$ & 0.991 & 0.07 \\
\hline \multirow{3}{*}{$\mathrm{N}_{40}$} & Second stage & $y=0.03 x+0.64$ & 0.968 & 0.03 \\
\hline & Third stage & $y=0.02 x+0.76$ & 0.961 & 0.02 \\
\hline & First stage & $y=0.07 x+0.005$ & 0.998 & 0.07 \\
\hline \multirow[t]{2}{*}{$\mathrm{N}_{60}$} & Second stage & $y=0.04 x+0.49$ & 0.989 & 0.04 \\
\hline & Third stage & $y=0.03 x+0.81$ & 0.973 & 0.03 \\
\hline \multicolumn{5}{|l|}{$\mathrm{Ni}$} \\
\hline & First stage & $y=0.33 x+0.12$ & 0.997 & 0.33 \\
\hline $\mathrm{N}_{0}$ & Second stage & $y=0.08 x+3.72$ & 0.997 & 0.08 \\
\hline & Third stage & $y=0.09 x+3.55$ & 0.975 & 0.09 \\
\hline & First stage & $y=0.36 x+0.22$ & 0.993 & 0.36 \\
\hline $\mathrm{N}_{20}$ & Second stage & $y=0.09 x+3.63$ & 0.990 & 0.09 \\
\hline & Third stage & $y=0.15 x+1.94$ & 0.986 & 0.15 \\
\hline & First stage & $y=0.33 x+0.47$ & 0.995 & 0.33 \\
\hline $\mathrm{N}_{40}$ & Second stage & $y=0.09 x+3.84$ & 0.985 & 0.09 \\
\hline & Third stage & $y=0.19 x+0.70$ & 0.982 & 0.19 \\
\hline & First stage & $y=0.36 x+0.33$ & 0.998 & 0.36 \\
\hline $\mathrm{N}_{60}$ & Second stage & $y=0.08 x+4.14$ & 0.999 & 0.08 \\
\hline & Third stage & $y=0.12 x+2.94$ & 0.965 & 0.12 \\
\hline $\mathrm{Pb}$ & & & & \\
\hline & First stage & $y=0.06 x+0.01$ & 0.850 & 0.06 \\
\hline $\mathrm{N}_{0}$ & Second stage & $y=0.36 x-4.53$ & 0.984 & 0.36 \\
\hline & Third stage & $y=0.11 x+2.54$ & 0.932 & 0.11 \\
\hline & First stage & $y=0.19 x-0.19$ & 0.937 & 0.19 \\
\hline $\mathrm{N}_{20}$ & Second stage & $y=0.62 x-6.97$ & 0.985 & 0.62 \\
\hline & Third stage & $y=0.34 x+0.84$ & 0.979 & 0.34 \\
\hline & First stage & $y=0.51 x-0.59$ & 0.993 & 0.51 \\
\hline $\mathrm{N}_{40}$ & Second stage & $y=0.92 x-6.62$ & 0.979 & 0.92 \\
\hline & Third stage & $y=0.40 x+6.29$ & 0.900 & 0.40 \\
\hline & First stage & $y=0.44 x-1.41$ & 0.895 & 0.44 \\
\hline $\mathrm{N}_{60}$ & Second stage & $y=1.07 x-10.21$ & 0.996 & 1.07 \\
\hline & Third stage & $y=1.00 x-9.26$ & 0.977 & 1.00 \\
\hline
\end{tabular}


TABLE 4: Fitting parameters of each kinetic model for HMs in the WFLZ soil in the TGR area under N deposition.

\begin{tabular}{|c|c|c|c|c|c|c|c|c|c|c|c|c|c|}
\hline \multirow[t]{2}{*}{ HMs } & \multirow[t]{2}{*}{$\mathrm{N}$ load } & \multicolumn{3}{|c|}{$\begin{array}{l}\text { Elovich equation } \\
\qquad S=a \ln t+b\end{array}$} & \multicolumn{3}{|c|}{$\begin{array}{l}\text { Double-constant equation } \\
\qquad \ln S=a \ln t+b\end{array}$} & \multicolumn{3}{|c|}{$\begin{array}{l}\text { First-order equation } \\
\operatorname{Ln}\left(S / S_{m}\right)=a t+b\end{array}$} & \multicolumn{3}{|c|}{$\begin{array}{l}\text { Parabolic diffusion } \\
\text { equation } S / S_{m}=a t^{1 / 2}+b\end{array}$} \\
\hline & & A & $B$ & $R^{2}$ & $a$ & $b$ & $R^{2}$ & $a$ & $b$ & $R^{2}$ & $a$ & $b$ & $R^{2}$ \\
\hline \multirow{4}{*}{$\mathrm{Cr}$} & $\mathrm{N}_{0}$ & 22.71 & -15.98 & 0.912 & 0.7375 & 1.6570 & 0.998 & 0.0495 & -0.2814 & 0.805 & 0.7342 & -0.7290 & 0.996 \\
\hline & $\mathrm{N}_{20}$ & 24.03 & -19.40 & 0.896 & 0.7999 & 1.4668 & 0.998 & 0.0537 & -0.3862 & 0.806 & 0.7824 & -0.9239 & 0.992 \\
\hline & $\mathrm{N}_{40}$ & 24.98 & -18.65 & 0.915 & 0.7807 & 1.5989 & 0.995 & 0.0517 & -0.2670 & 0.783 & 0.8069 & -0.8541 & 0.997 \\
\hline & $\mathrm{N}_{60}$ & 27.22 & -18.29 & 0.926 & 0.7433 & 1.8387 & 0.993 & 0.0490 & -0.0745 & 0.774 & 0.8746 & -0.8052 & 0.999 \\
\hline \multirow{4}{*}{$\mathrm{Cu}$} & $\mathrm{N}_{0}$ & 21.41 & -15.98 & 0.888 & 0.7342 & 1.5831 & 0.997 & 0.0503 & -3.5867 & 0.837 & 0.0283 & -0.0308 & 0.987 \\
\hline & $\mathrm{N}_{20}$ & 21.91 & -12.55 & 0.937 & 0.6957 & 1.8161 & 0.990 & 0.0457 & -3.3657 & 0.765 & 0.0283 & -0.0208 & 0.997 \\
\hline & $\mathrm{N}_{40}$ & 22.03 & -13.22 & 0.920 & 0.6825 & 1.8470 & 0.997 & 0.0458 & -3.3738 & 0.805 & 0.0288 & -0.0234 & 0.997 \\
\hline & $\mathrm{N}_{60}$ & 24.51 & -14.23 & 0.919 & 0.6826 & 1.9633 & 0.992 & 0.0455 & -3.2502 & 0.788 & 0.0320 & -0.0249 & 0.995 \\
\hline \multirow{4}{*}{$\mathrm{Cd}$} & & 1235 & -0.7942 & 0.920 & 0.7580 & -1.4149 & 0.988 & 0.0504 & -6.0 & 0.781 & 0.0023 & -0.0022 & 0.989 \\
\hline & $\mathrm{N}_{20}$ & 1.2880 & -1.1353 & 0.909 & 0.9208 & -1.8707 & 0.985 & 0.0599 & -6.2842 & 0.745 & 0.0026 & -0.0033 & 0.993 \\
\hline & $\mathrm{N}_{40}$ & 1.1909 & -0.7221 & 0.954 & 0.7594 & -1.3068 & 0.973 & 0.0485 & -5.9317 & 0.710 & 0.0024 & -0.0017 & 0.988 \\
\hline & $\mathrm{N}_{60}$ & 1.3679 & -1.0362 & 0.932 & 0.8253 & -1.4479 & 0.986 & 0.0536 & -5.9971 & 0.745 & 0.0028 & -0.0028 & 0.995 \\
\hline \multirow{4}{*}{$\mathrm{Ni}$} & $\mathrm{N}_{0}$ & 5.191 & -2.730 & 0.961 & 0.7325 & 0.2866 & 0.965 & 0.0461 & -3.7091 & 0.685 & 0.0196 & -0.0113 & 0.977 \\
\hline & $\mathrm{N}_{20}$ & 5.257 & -2.398 & 0.950 & 0.6747 & 0.5061 & 0.969 & 0.0432 & -3.5899 & 0.713 & 0.0199 & -0.0095 & 0.975 \\
\hline & $\mathrm{N}_{40}$ & 5.476 & -2.533 & 0.945 & 0.6677 & 0.5663 & 0.976 & 0.0430 & -3.5448 & 0.727 & 0.0209 & -0.0107 & 0.983 \\
\hline & $\mathrm{N}_{60}$ & 5.289 & -2.055 & 0.966 & 0.6673 & 0.5661 & 0.961 & 0.0419 & -3.5221 & 0.678 & 0.0199 & -0.0064 & 0.971 \\
\hline \multirow{4}{*}{$\mathrm{Pb}$} & $\mathrm{N}_{0}$ & 5.730 & -8.348 & 0.698 & 1.4801 & -2.6781 & 0.915 & 0.1096 & -5.4861 & 0.898 & 0.0367 & -0.0859 & 0.873 \\
\hline & $\mathrm{N}_{20}$ & 11.39 & -16.09 & 0.717 & 1.3214 & -1.4157 & 0.924 & 0.0986 & -4.4358 & 0.921 & 0.0730 & -0.1654 & 0.893 \\
\hline & $\mathrm{N}_{40}$ & 18.21 & -22.30 & 0.817 & 1.1846 & -0.3050 & 0.955 & 0.0828 & -3.3801 & 0.837 & 0.1128 & -0.2150 & 0.952 \\
\hline & $\mathrm{N}_{60}$ & 23.20 & -34.11 & 0.729 & 2.1463 & -3.3404 & 0.975 & 0.1416 & -4.9676 & 0.760 & 0.1482 & -0.3483 & 0.904 \\
\hline
\end{tabular}

Note. Correlation coefficients $\left(R^{2}\right)$ higher than 0.9 are in bold.

Based on the correlation coefficients $\left(R^{2}\right)$ fitted by each equation (Table 4), it was found that the double-constant equation and parabolic equation can better describe the kinetic process of leaching of HMs in the WFLZ soil by simulated $\mathrm{N}$ deposition. At the same time, $\mathrm{Cr}, \mathrm{Cu}, \mathrm{Cd}$, and $\mathrm{Ni}$ had a relatively high correlation coefficient of the Elovich equation, while $\mathrm{Pb}$ had a relatively higher correlation $\mathrm{co}-$ efficient of the first-order equation. The results indicated that being controlled by the intricate reaction rate and the multidiffusion factors were the common kinetics' features of these HMs. In addition, the relatively good fitting of the Elovich equation for $\mathrm{Cr}, \mathrm{Cu}, \mathrm{Cd}$, and $\mathrm{Ni}$ suggested that the mechanism of leaching and release of these elements in WFLZ soil was also influenced by the changes in activation energy, rather than a single surface diffusion process, while the release of $\mathrm{Pb}$ was also affected by single surface diffusion.

3.4. Activation of HMs. The exchangeable fraction of $\mathrm{HMs}$ was relatively low, but its mobility and activity were the highest in $\mathrm{HM}$ forms. In this study, exchangeable fractions of $\mathrm{Cd}, \mathrm{Cu}, \mathrm{Ni}, \mathrm{Pb}$, and $\mathrm{Cr}$ were $0.13,0.20,0.47,0.60$, and $0.81 \mathrm{mg} / \mathrm{kg}$, accounting for $4.90 \%, 0.54 \%, 0.96 \%, 0.90 \%$, and $1.05 \%$ of the total mass contents, respectively. Figure 4 presents the changes of an exchangeable fraction of HMs before (original) and after leaching $\left(\mathrm{N}_{0}, \mathrm{~N}_{20}, \mathrm{~N}_{40}\right.$, and $\left.\mathrm{N}_{60}\right)$. It can be seen that the $\mathrm{N}$ deposition stimulated the increase of $\mathrm{HMs}^{\prime}$ exchangeable fraction. For $\mathrm{Cr}, \mathrm{Cu}$, and $\mathrm{Pb}$, the exchangeable fractions between each treatment of $\mathrm{N}$ deposition had no significant change $(p>0.05)$. For $\mathrm{Cd}$, the exchangeable fractions after leaching $\left(\mathrm{N}_{0}, \mathrm{~N}_{20}, \mathrm{~N}_{40}\right.$, and $\left.\mathrm{N}_{60}\right)$ were significantly higher than the original one, but there were no significant differences between the $\mathrm{N}$-containing

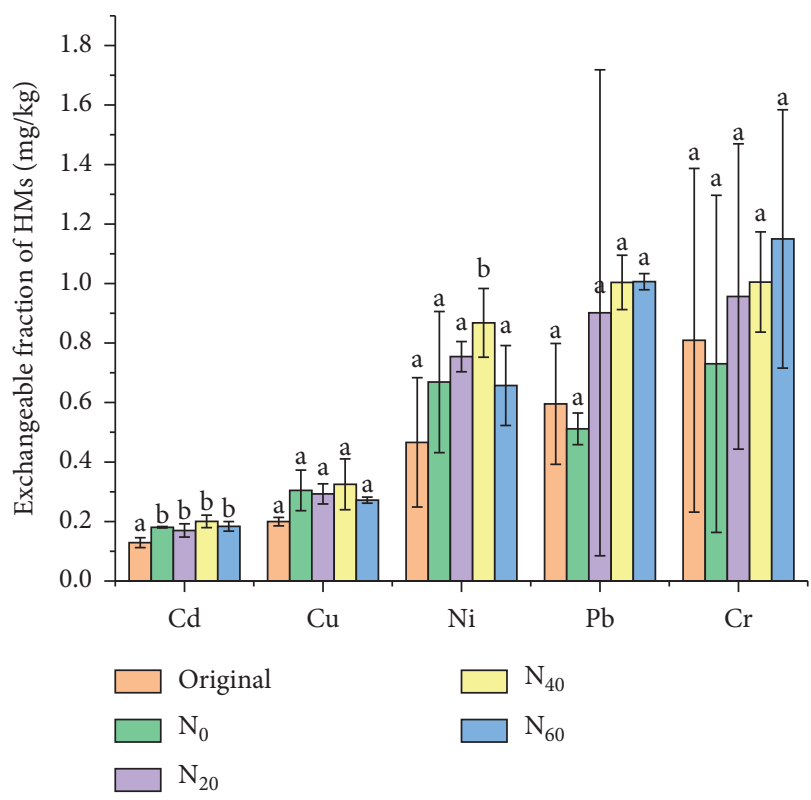

FIgURE 4: Changes of exchangeable fractions of HMs before (original) and after leaching $\left(\mathrm{N}_{0}, \mathrm{~N}_{20}, \mathrm{~N}_{40}\right.$, and $\left.\mathrm{N}_{60}\right)$.

group $\left(\mathrm{N}_{20}, \mathrm{~N}_{40}\right.$, and $\left.\mathrm{N}_{60}\right)$ and the $\mathrm{N}$-free group $\left(\mathrm{N}_{0}\right)$. This may be affected by the $\mathrm{pH}$ (5.5) rather than the $\mathrm{N}$ of the leaching solution. For $\mathrm{Ni}$, the exchangeable fraction after leaching by $\mathrm{N}_{40}$ was significantly higher than other groups. It was consistent with the aforementioned release amount of $\mathrm{Ni}$. The results showed that $\mathrm{N}$ deposition was more conducive to promoting the activation of $\mathrm{Ni}$ compared with $\mathrm{Cd}$, $\mathrm{Cr}, \mathrm{Cu}$, and $\mathrm{Pb}$. 


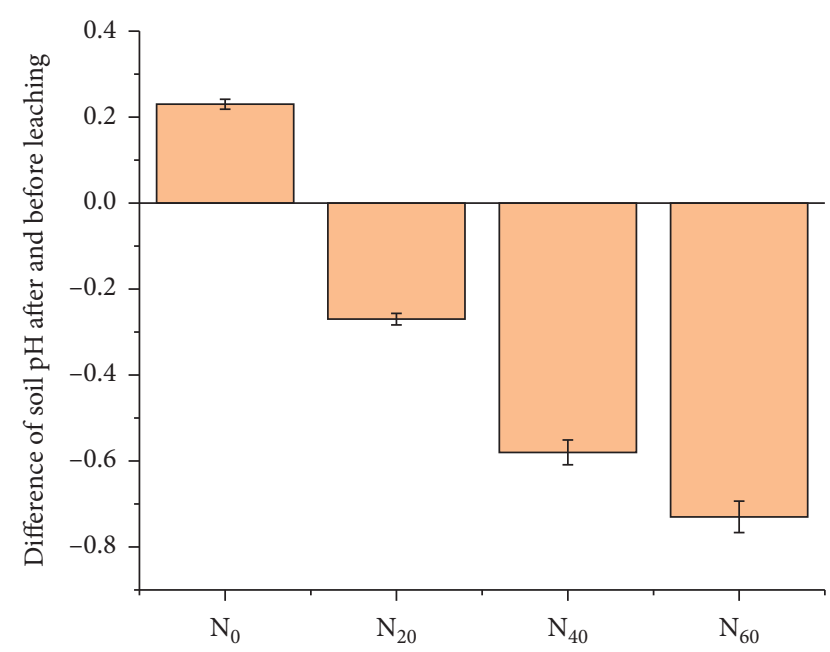

Figure 5: Changes of soil $\mathrm{pH}$ after and before leaching at different $\mathrm{N}$ deposition levels.

\section{Discussion}

The mechanism of $\mathrm{N}$ deposition-induced acidification of soil is different from acid deposition. Acidic deposition brings $\mathrm{H}^{+}$directly into the soil to activate trace metals, and the $\mathrm{H}^{+}$ can displace the exchangeable fractions from their binding sites [26, 27]. Different HMs have different sensitivity to acid deposition. For purple soil in the Sichuan Basin, the transformability and mobility of $\mathrm{Cu}$ and $\mathrm{Zn}$ by acid deposition were higher than that of $\mathrm{Pb}$ and $\mathrm{Cd}$ [28]. However, the activation and migration of HMs induced by $\mathrm{N}$ deposition have latent characteristics. First, $\mathrm{NH}_{4}{ }^{+}$displaces the base cations, resulting in the base cations being lost with $\mathrm{NO}_{3}{ }^{-}$ and reducing the buffering capacity for soil acidity [29]. Additionally, plant-induced assimilation $\left(\mathrm{NH}_{4}{ }^{+}+\mathrm{ROH} \longrightarrow\right.$ $\mathrm{RNH}_{2}+\mathrm{H}_{2} \mathrm{O}+\mathrm{H}^{+}$) and soil-induced nitrification would release $\mathrm{H}^{+}$to cause soil acidification [30], and the $\mathrm{H}^{+}$further promotes HMs' transformation and migration.

In this study, although this decrease was not significant ( $p>0.05$ ), the $\mathrm{pH}$ of WLFZ soil decreased with increasing $\mathrm{N}$ deposition (Figure 5), showing that $\mathrm{N}$ deposition has a potential acidification effect. Since this study did not involve plant ecosystems, this insignificant acidification may be attributed to the nitrification of soil $\mathrm{NH}_{4}{ }^{+}$because $\mathrm{NH}_{4} \mathrm{NO}_{3}$ can promote the growth of soil nitrifying bacteria and accelerate the rate of soil nitrification, thereby accelerating soil acidification [31]. In addition, the leaching amounts of base cations $\left(\mathrm{K}^{+}, \mathrm{Na}^{+}, \mathrm{Ca}^{2+}\right.$, and $\left.\mathrm{Mg}^{2+}\right)$ were increased as increasing $\mathrm{N}$ deposition (Figure 6), and the concentrations of base cations were all positively correlated with $\mathrm{NO}_{3}{ }^{-}$in leachate $\left(r^{2}\right.$ ranged from $\left.0.16 \sim 0.92, p<0.01\right)$. Therefore, it was the $\mathrm{NO}_{3}{ }^{-}$that carried the base cations to loss with wet deposition. With the loss of base cations, the acid buffering of soil decreased, and toxic HMs began to active and migrate, resulting in ecological harm.

The WLFZ is a land-water interlaced zone. Thus there exist frequent material and energy exchanges between the WLFZ soil and the water body in the TGR area [32]. The high background content and the accumulating HMs in

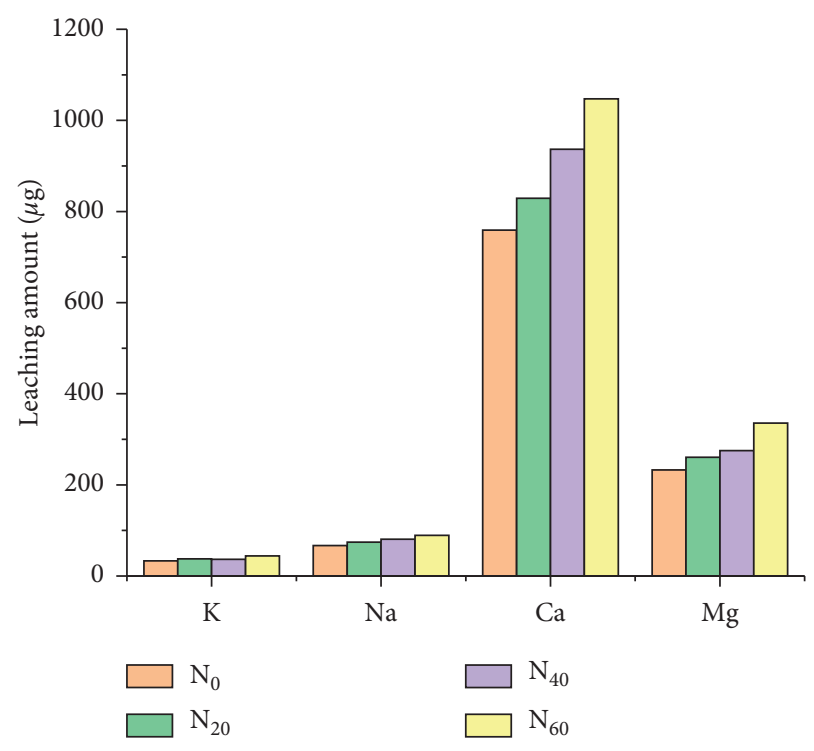

FIGURE 6: Leaching amounts of base cations under $\mathrm{N}$ deposition.

WLFZ soil as a result of external inputs (e.g., sewage discharge, agricultural nonpoint sources) have become the potential pollution sources of the TGR $[1,33,34]$. Under the influence of external environmental disturbance, these HMs will be activated and migrated, causing harm to the ecosystem. This study showed that $\mathrm{N}$ deposition was a nonnegligible factor driving the transformation and migration of HMs. A moderate level of $\mathrm{N}$ deposition $(40 \mathrm{kgN} /(\mathrm{ha} \cdot \mathrm{yr})$ ) could cause significant activation of $\mathrm{Ni}$ and cause migration of $\mathrm{Cd}, \mathrm{Cu}, \mathrm{Pb}$, and $\mathrm{Cr}$ with wet deposition. According to our previous study, the $\mathrm{N}$ flux of wet deposition in the entire TGR area ranged from 12.17 to $51.93 \mathrm{kgN} /$ (ha.yr), and it could exceed $40 \mathrm{kgN} /(\mathrm{ha} \cdot \mathrm{yr}$ ) in the upstream area [8]. Therefore, the influence of $\mathrm{N}$ deposition on the migration and transformation of HMs in the soil of the WFLZ is worthy of in-depth exploration.

\section{Conclusions}

The effect of $\mathrm{N}$ deposition on the migration and transformation of HMs in the fluctuation zone of the TGR was investigated in this study. As the $\mathrm{N}$ deposition increased, the amounts of leached-out HMs increased. The cumulative release amounts of $\mathrm{Cr}$ and $\mathrm{Cu}$ were much higher than those of $\mathrm{Pb}, \mathrm{Ni}$, and $\mathrm{Cd}$, whereas that of $\mathrm{Pb}$ showed significant differences between $\mathrm{N}$ deposition groups. Three-stage dissolution for $\mathrm{Cu}$ and $\mathrm{Cd}$ was observed. Their dissolution rates were gradually lower, and only physical elution was involved. In contrast, the dissolution rate of $\mathrm{Ni}$ increased at the third stage, likely caused by the activation effects. In comparison, $\mathrm{Cr}$ only experienced two stages of rapid and slow dissolution. The double-constant equation and the parabolic diffusion equation could well describe the leaching process of HMs, indicating that the release process of the HMs was a diffusion kinetic process with uneven energy distribution and controlled by multiple diffusion factors. After the $\mathrm{N}$ deposition treatment, the exchangeable fractions of HMs 
increased to varying degrees, of which $\mathrm{Ni}$ was most significant, indicating that $\mathrm{N}$ deposition would enhance the ecological risk of HM pollution in the TGR area, a unique region with a vulnerable ecology environment.

\section{Data Availability}

The data used to support the findings of this study are included within the article.

\section{Conflicts of Interest}

The authors declare that there are no conflicts of interest regarding the publication of this paper.

\section{Acknowledgments}

This work was supported by the National Natural Science Foundation of China (No. 31670467), the Science and Technology Commission of Chongqing project (No. cstc2018jcyjAX0236), the West Action Plan of the Chinese Academy of Science (No. KZCX2-XB3-14), and the open fund of CAS Key Laboratory of Reservoir Aquatic Environment.

\section{References}

[1] C. Ye, S. Li, Y. Zhang, and Q. Zhang, "Assessing soil heavy metal pollution in the water-level-fluctuation zone of the Three Gorges Reservoir, China," Journal of Hazardous Materials, vol. 191, no. 1-3, pp. 366-372, 2011.

[2] X. Zhao, B. Gao, D. Xu, L. Gao, and S. Yin, "Heavy metal pollution in sediments of the largest reservoir (Three Gorges Reservoir) in China: a review," Environmental Science and Pollution Research, vol. 24, no. 26, pp. 20844-20858, 2017.

[3] S. Pei, Z. Jian, Q. Guo et al., "Temporal and spatial variation and risk assessment of soil heavy metal concentrations for water-level-fluctuating zones of the Three Gorges Reservoir," Journal of Soils and Sediments, vol. 18, no. 9, pp. 2924-2934, 2018.

[4] Q. Y. Chen, S. Sun, D. L. Yin, L. M. Wang, C. Zhang, and D. Y. Wang, "Effects of agricultural activities on soil mercury changes in the water-level-fluctuating zone of the three Gorges reservoir," Environ Sci, vol. 39, pp. 2456-2463, 2018, in Chinese.

[5] F. Ye, M. H. Ma, S. J. Wu et al., "Soil properties and distribution in the riparian zone: the effects of fluctuations in water and anthropogenic disturbances," European Journal of Soil Science, vol. 70, no. 3, pp. 664-673, 2019.

[6] Y. Wang, P. Huang, F. Ye et al., "Nitrite-dependent anaerobic methane oxidizing bacteria along the water level fluctuation zone of the Three Gorges Reservoir," Applied Microbiology and Biotechnology, vol. 100, no. 4, pp. 1977-1986, 2016.

[7] G. Yu, Y. Jia, N. He et al., "Stabilization of atmospheric nitrogen deposition in China over the past decade," Nature Geoscience, vol. 12, no. 6, pp. 424-429, 2019.

[8] Q. Leng, J. Cui, F. Zhou et al., "Wet-only deposition of atmospheric inorganic nitrogen and associated isotopic characteristics in a typical mountain area, southwestern China," Science of the Total Environment, vol. 616-617, pp. 55-63, 2018.

[9] L. Zhang, M. Tian, C. Peng et al., "Nitrogen wet deposition in the Three Gorges Reservoir area: characteristics, fluxes, and contributions to the aquatic environment," Science of the Total Environment, vol. 738, Article ID 140309, 2020.

[10] C. J. Stevens, N. B. Dise, and D. J. Gowing, "Regional trends in soil acidification and exchangeable metal concentrations in relation to acid deposition rates," Environmental Pollution, vol. 157, no. 1, pp. 313-319, 2009.

[11] L. Zhang, B. Qiao, H. Wang et al., "Chemical characteristics of precipitation in a typical urban site of the hinterland in three Gorges reservoir, China," Journal of Chemistry, vol. 2018, Article ID 2914313, 10 pages, 2018.

[12] N. Yan, W. Liu, H. Xie et al., "Distribution and assessment of heavy metals in the surface sediment of Yellow River, China," Journal of Environmental Sciences, vol. 39, pp. 45-51, 2016.

[13] Q. Li, Q. Zhang, H. L. Liu, and X. Zhou, "The investigation on the heavy metal pollution of the soil in inundated area in the ChongQing Reservoir," Studies on Trace Element Health, vol. 24, pp. 34-36, 2007, in Chinese.

[14] L. Chen, D. F. Flynn, X. Jing, P. Kuhn, T. Scholten, and J. S. He, "A comparison of two methods for quantifying soil organic carbon of alpine grasslands on the Tibetan Plateau," PLoS One, vol. 10, p. e0126372, 2015.

[15] A. Tessler, P. G. C. Campbell, and M. Bisson, "Sequential extraction procedure for the speciation of particulate trace metals," Analytical Chemistry, vol. 51, pp. 844-851, 1979.

[16] Y. Yang, L. Liang, and D. Wang, "Effect of dissolved organic matter on adsorption and desorption of mercury by soils," Journal of Environmental Sciences, vol. 20, no. 9, pp. 10971102, 2008.

[17] L. Peng, P. Liu, X. Feng et al., "Kinetics of heavy metal adsorption and desorption in soil: developing a unified model based on chemical speciation," Geochimica et Cosmochimica Acta, vol. 224, pp. 282-300, 2018.

[18] R. Li, W. Tan, G. Wang et al., "Nitrogen addition promotes the transformation of heavy metal speciation from bioavailable to organic bound by increasing the turnover time of organic matter: an analysis on soil aggregate level," Environmental Pollution, vol. 255, Article ID 113170, 2019.

[19] A. Ertani, A. Mietto, M. Borin, and S. Nardi, "Chromium in agricultural soils and crops: a review," Water Air and Soil Pollution, vol. 228, 2017.

[20] J. Tang, Q. Xue, H. Chen, and W. Li, "Mechanistic study of lead desorption during the leaching process of ion-absorbed rare earths: $\mathrm{pH}$ effect and the column experiment," Environmental Science and Pollution Research, vol. 24, no. 14, pp. 12918-12926, 2017.

[21] S. Li, B. Fang, D. Wang, X. Wang, X. Man, and X. Zhang, "Leaching characteristics of heavy metals and plant nutrients in the sewage sludge immobilized by composite phosphorusbearing materials," International Journal of Environmental Research and Public Health, vol. 16, no. 24, p. 5159, 2019.

[22] J. Qiao, J. Tang, and Q. Xue, "Study on Pb release by several new lixiviants in weathered crust elution-deposited rare earth ore leaching process: behavior and mechanism," Ecotoxicology and Environmental Safety, vol. 190, Article ID 110138, 2020.

[23] H. R. Motaghian and A. R. Hosseinpur, "Zinc desorption kinetics in wheat (Triticum Aestivum L.) rhizosphere in some sewage sludge amended soils," Journal of Soil Science and Plant Nutrition, vol. 13, pp. 664-678, 2013.

[24] H. I. Inyang, A. Onwawoma, and S. Bae, "The Elovich equation as a predictor of lead and cadmium sorption rates on contaminant barrier minerals," Soil and Tillage Research, vol. 155, pp. 124-132, 2016.

[25] D. L. Sparks, "Kinetics of ionic reactions in clay minerals and soils," Advances in Agronomy, vol. 38, pp. 231-266, 1986. 
[26] L. Liu, D. Luo, G. Yao et al., "Comparative activation process of $\mathrm{Pb}, \mathrm{Cd}$ and $\mathrm{Tl}$ using chelating agents from contaminated red soils," International Journal of Environmental Research and Public Health, vol. 17, no. 2, p. 497, 2020.

[27] A. G. Caporate and A. Violante, "Chemical processes affecting the mobility of heavy metals and metalloids in soil environments," Current Pollution Reports, vol. 2, pp. 15-27, 2016.

[28] S. A. Zheng, X. Zheng, and C. Chen, "Leaching behavior of heavy metals and transformation of their speciation in polluted soil receiving simulated acid rain," PLoS One, vol. 7, Article ID e49664, 2012.

[29] W. D. Bowman, C. C. Cleveland, L. Halada, J. Hreško, and J. S. Baron, "Negative impact of nitrogen deposition on soil buffering capacity," Nature Geoscience, vol. 1, no. 11, pp. 767-770, 2008.

[30] N. S. Bolan, D. C. Adriano, and D. Curtin, "Soil acidification and liming interactions with nutrient and heavy metal transformation and bioavailability," Advances in Agronomy, vol. 78, pp. 215-272, 2003

[31] G. Yan, Y. Xing, S. Han, J. Zhang, Q. Wang, and C. Mu, "Long-time precipitation reduction and nitrogen deposition increase alter soil nitrogen dynamic by influencing soil bacterial communities and functional groups," Pedosphere, vol. 30, no. 3, pp. 363-377, 2020.

[32] X.-z. Yuan, Y.-w. Zhang, H. Liu, S. Xiong, B. Li, and W. Deng, "The littoral zone in the Three Gorges Reservoir, China: challenges and opportunities," Environmental Science and Pollution Research, vol. 20, no. 10, pp. 7092-7102, 2013.

[33] J. Tang, Y. P. Zhong, and L. Wang, "Background value of soil heavy metal in the three Gorges reservoir District," Chinese Journal of Eco-Agriculture, vol. 16, no. 4, pp. 848-852, 2008, in Chinese.

[34] C. Ye, S. Li, Y. Zhang, X. Tong, and Q. Zhang, "Assessing heavy metal pollution in the water level fluctuation zone of China's Three Gorges Reservoir using geochemical and soil microbial approaches," Environmental Monitoring and Assessment, vol. 185, no. 1, pp. 231-240, 2013. 